\title{
THE EFFECT OF OXYGEN STAGING ON NITROGEN CONVERSION IN OXY-FUEL CFB ENVIRONMENT
}

\author{
Sylwia Jankowska*, Tomasz Czakiert, Grzegorz Krawczyk, Paweł Borecki, \\ Łukasz Jesionowski, Wojciech Nowak \\ Czestochowa University of Technology, Institute of Advanced Energy Technologies, Dabrowskiego \\ 73, Czestochowa 42-200, Poland
}

\begin{abstract}
This paper presents a study on nitrogen conversion in oxy-fuel coal combustion in a pilot scale CFB $0.1 \mathrm{MW}_{\text {th }}$ facility. The paper is focused on fuel-N behaviour in the combustion chamber when the combustion process is accomplished under oxy-fuel CFB conditions. The analysis is based on infurnace sampling of flue gas and calculations of the conversion ratios of fuel-nitrogen (fuel-N) to $\mathrm{NO}, \mathrm{NO}_{2}, \mathrm{~N}_{2} \mathrm{O}, \mathrm{NH}_{3}$ and $\mathrm{HCN}$. For the tests, $\mathrm{O}_{2} / \mathrm{CO}_{2}$ mixtures with the oxygen content of $21 \mathrm{vol} . \%$ (primary gas) and with the oxygen content varied from 21 to 35 vol.\% (secondary gas), were used as the fluidising gas. Measurements were carried out in 4 control points located along the combustion chamber: $0.43 \mathrm{~m}, 1.45 \mathrm{~m}, 2.50 \mathrm{~m}$ and $4.88 \mathrm{~m}$. Results presented below indicate that an increased oxygen concentration in the higher part of the combustion chamber has strong influence on the behaviour of fuel based nitrogen compounds.
\end{abstract}

Keywords: oxy-fuel, fuel-N, CFB

\section{INTRODUCTION}

Present regulations on environmental protection force scientists to search for new technologies to sustain energetic stability. The most promising technology of energy production can be the oxy-fuel (Toftegaard et al., 2010). First pilot scale installations were constructed between 80's and 90's and the beginning of 2000, in Canada (Hirma et al., 1998), USA (Liljedahl et al., 2006), Finland (Eriksson et al., 2008) and Poland (Czakiert et al., 2004). Joined advantages of circulating fluidised bed technology (flexibility, low emissions) and oxy-fuel (reduction of $\mathrm{CO}_{2}$ emission) make this solution to be very promising.

Problems associated with $\mathrm{NO}_{\mathrm{x}}$ creation and removal in the oxy-fuel combustion process are important scientific issues, researched by many $R \& D$ centers both in Poland (Lasek, 2013; and Pawlak-Kruczek et al., 2013) as well as in the rest of the world (Normann et al., 2009). $\mathrm{NO}_{\mathrm{X}}$ reduction is one of the biggest advantages of oxy-fuel combustion, therefore it is widely studied. Currently this method allows for $\mathrm{NO}_{\mathrm{X}}$ reduction up to $50 \%$ compared to the traditional combustion, but there is no doubt it can still be improved.

In this article the authors focus on fuel-N behaviour in the circulating fluidised bed combustion process of coal in $\mathrm{O}_{2} / \mathrm{CO}_{2}$ atmosphere. 


\section{EXPERIMENTAL}

\subsection{Pilot-scale Oxy-CFB tests}

The investigations of nitrogen conversion under oxy-fuel conditions were carried out using a $0.1 \mathrm{MW}_{\text {th }}$ CFB test rig (Fig. 1). The unit consists of a $0.1 \mathrm{~m}$ inner diameter and approximately $5.0 \mathrm{~m}$ tall combustion chamber, connected to a $0.25 \mathrm{~m}$ inner diameter hot cyclone. The return leg includes $0.075 \mathrm{~m}$ inner diameter downcomer and a non-mechanical loopseal. Fuel is fed continuously by a screw feeder located on a return leg, between the combustion chamber and the loopseal.

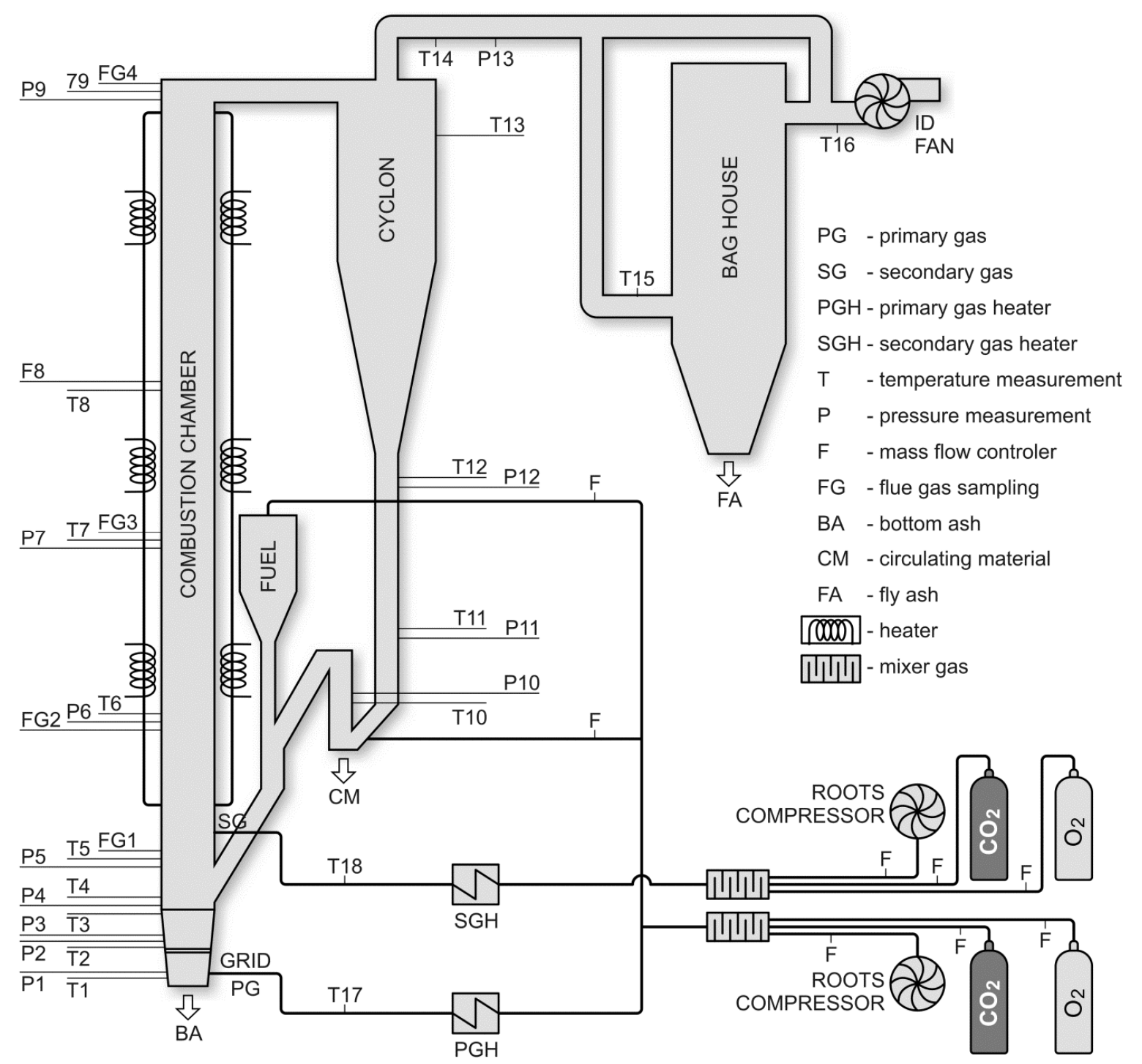

Fig. 1. Oxy-fuel CFB test rig $\left(0.1 \mathrm{MW}_{\text {th }}\right)$

Before leaving the installation flue gas passes through a single fabric baghouse filter that can be bypassed if necessary. The flue gas leaving the baghouse (or bypassing the baghouse) is vented with an induced draft (ID) fan to the atmosphere, through a stack. The installation is equipped with an electric heating system that is used to heat the unit to (or beyond) the ignition point of the fuel being used. The primary gas (PG) is supplied through a ceramic grid at the bottom of the combustion chamber. The secondary gas (SG) can be supplied at the level of $0.55 \mathrm{~m}$ above the grid through a common-rail fitted with three nozzles. The oxygen fractions in PG and SG can be set differently by means of two 
independent flow mixers. Both oxygen and $\mathrm{CO}_{2}$ are provided from gas cylinders. Two electric heaters are used for pre-heating of primary and secondary gases.

The test rig is equipped with an advanced data acquisition system for temperature $(\mathrm{T})$ and pressure $(\mathrm{P})$ measurements, as well as a number of ports for flue gas (FG), bottom ash (BA), fly ash (FA), and circulating material (CM) sampling.

\subsection{Test conditions and measurements}

The temperature in the combustion chamber varies in the range of $T=825-860^{\circ} \mathrm{C}$ on average, depending on the oxygen fraction in the inlet gas (see Fig. 2a). The pressure drop in the combustion chamber was kept at a level of $2500 \mathrm{~Pa}$ (see Fig. 2b). Fourier transform infrared ( $\mathrm{NO}, \mathrm{NO}_{2}, \mathrm{~N}_{2} \mathrm{O}, \mathrm{NH}_{3}$, $\mathrm{HCN}, \mathrm{CO}_{2}, \mathrm{CO}$ and the group of $\left.\mathrm{CxHy}\right)$ and paramagnetic $\left(\mathrm{O}_{2}\right)$ measurement methods were employed for the flue gas components considered in this paper. Sampling frequency for all the above-mentioned variables was $1 \mathrm{~Hz}$. Recording time was established at $3600 \mathrm{~s}$ and started after reaching stable operating conditions in the combustor. The whole list of temperature and pressure measurement points as well as flue gas sampling ports is given in Table 1.

For the tests, $\mathrm{O}_{2} / \mathrm{CO}_{2}$ mixtures with the oxygen content of 21 vol.\% (primary gas) and with different content of oxygen for secondary gas: $21,25,30,35$ vol.\%, were used as fluidising agent. PG/SG volume ratio was established at 70/30. Polish bituminous coal with nitrogen content of $0.75-0.97 \%$, particle size of $d_{p}=0-2500 \mu \mathrm{m}, d_{3,2}=438 \mu \mathrm{m}$ and of properties given in Table 2 was applied as fuel. Test results conducted by Toftegaard et al. (2010), Glarborg et al. (2003) and Williams (2012), show a strong corelation between the amout of nitrogen bounded in coal/biomass, and the amout of NOx created in combustion process.

Table 1. Height of temperature and pressure measurement points and flue gas sampling ports

\begin{tabular}{|c|c|c|c|}
\hline $\begin{array}{l}\text { Location of } T \\
\text { measurement point } \\
\text { with respect to the } \\
\text { grid in combustion } \\
\text { chamber [m] }\end{array}$ & $\begin{array}{l}\text { Location of } P \\
\text { measurement point } \\
\text { with respect to the } \\
\text { grid in combustion } \\
\text { chamber [m] }\end{array}$ & $\begin{array}{l}\text { Location of } F G \\
\text { sampling point with } \\
\text { respect to the grid } \\
\text { in combustion } \\
\text { chamber [m] }\end{array}$ & $\begin{array}{l}\text { Location of other } \\
\text { points with respect to the grid in } \\
\text { combustion chamber }[\mathrm{m}]\end{array}$ \\
\hline $\mathrm{T} 1--0.07$ & $\mathrm{P} 1--0.07$ & FG1 -0.43 & grid, 0.00 \\
\hline $\mathrm{T} 2-0.02$ & $\mathrm{P} 2-0.01$ & $\mathrm{FG} 2-1.45$ & return solids entrance, 0.28 \\
\hline $\mathrm{T} 3-0.20$ & P3 -0.065 & FG3 -2.50 & solids feed point, 0.35 \\
\hline $\mathrm{T} 4-0.30$ & $\mathrm{P} 4-0.20$ & FG4 - 4.88 & secondary gas distribution point, 0.55 \\
\hline $\mathrm{T} 5-0.51$ & $\mathrm{P} 5-0.51$ & & fuel feed point, 0.65 \\
\hline $\mathrm{T} 6-1.49$ & $\mathrm{P} 6-1.45$ & & \\
\hline $\mathrm{T} 7,2.50$ & $\mathrm{P} 7-2.44$ & & \\
\hline $\mathrm{T} 8-3.41$ & $\mathrm{P} 8-3.42$ & & \\
\hline $\mathrm{T} 9-5.21$ & $\mathrm{P} 9-4.63$ & & \\
\hline $\mathrm{T} 10-5.37$ & $\mathrm{P} 10-0.55$ & & \\
\hline $\mathrm{T} 11-0.65$ & $\mathrm{P} 11-1.03$ & & \\
\hline $\mathrm{T} 12-1.14$ & $\mathrm{P} 12-2.69$ & & \\
\hline $\mathrm{T} 13-2.76$ & $\mathrm{P} 13-5.86$ & & \\
\hline \multicolumn{2}{|l|}{$\mathrm{T} 14-5.77$} & & \\
\hline $\mathrm{T} 15-\mathrm{T} 18 \mathrm{n} / \mathrm{a}$ & & & \\
\hline
\end{tabular}


Table 2. Properties of applied fuel

\begin{tabular}{|l|c|}
\cline { 2 - 2 } \multicolumn{1}{c|}{} & Bituminous coal \\
\hline Lower heating value (LHV) $(\mathrm{kJ} / \mathrm{kg})$ & $23165-23569$ \\
\hline $\mathrm{C}(\mathrm{wt} \%)$ & $60.6-61.8$ \\
\hline $\mathrm{S} \mathrm{comb}(\mathrm{wt} \%)$ & $1.13-1.52$ \\
\hline $\mathrm{H}(\mathrm{wt} \%)$ & $3.85-3.92$ \\
\hline $\mathrm{N}(\mathrm{wt} \%)$ & $0.75-0.97$ \\
\hline $\mathrm{O}($ by difference) $(\mathrm{wt} \%)$ & $12.28-15.23$ \\
\hline Moisture content $(\mathrm{wt} \%)$ & $8.4-11.5$ \\
\hline Ash content $(\mathrm{wt} \%)$ & $8.5-9.6$ \\
\hline Volatile matter $(\mathrm{wt} \%)$ & $29.8-30.6$ \\
\hline Fixed carbon $($ by difference) $(\mathrm{wt} \%)$ & $48.9-52.5$ \\
\hline
\end{tabular}

\subsection{Calculation methods}

The analysis was based on changes in the conversion rate (CR) of nitrogen $\left(N_{\text {fuel }}\right)$ to: $\mathrm{NO}-\left(C R_{\mathrm{N} \rightarrow \mathrm{NO}}\right)$, $\mathrm{NO}_{2}-\left(C R_{\mathrm{N} \rightarrow \mathrm{NO} 2}\right), \mathrm{N}_{2} \mathrm{O}-\left(C R_{\mathrm{N} \rightarrow \mathrm{N} 2 \mathrm{O}}\right), \mathrm{NH}_{3}-\left(C R_{\mathrm{N} \rightarrow \mathrm{NH} 3}\right), \mathrm{HCN}-\left(C R_{\mathrm{N} \rightarrow \mathrm{HCN}}\right)$, which were calculated as described in Czakiert et al. (2012). A comparison of the corresponding factor values on each level of the combustion chamber, allows to trace each component's conversion course, since the devolatilisation of fuel, until the component's exit from the test rig.

\section{RESULTS AND DISCUSSION}

\subsection{Temperature distributions}

The test rig was not equipped with heat exchangers, therefore the temperature was controlled by preheating inlet gas or removing parts of insulation from the return leg and/or combustion chamber. All temperature profiles plotted in Fig. $2 \mathrm{a}$ are within $\pm 2.5 \%$ range of the planned temperature value $\left(850^{\circ} \mathrm{C}\right)$.
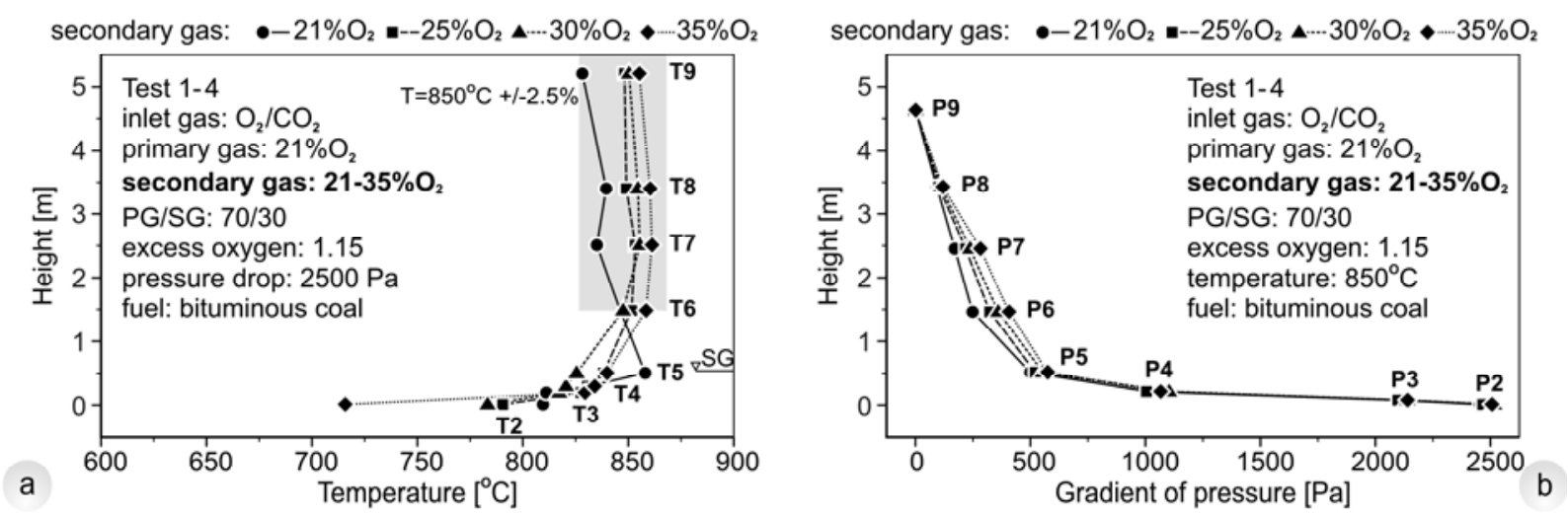

Fig. 2. Temperature distributions (a) and pressure profiles (b) along the height of the combustion chamber

The temperature profile of test $1\left(21 \%\right.$ vol. $\mathrm{O}_{2}$ in secondary gas) has $\mathrm{T} 5(0.51 \mathrm{~m})$ point distinctly shifted from the corresponding points in other testes (2-4). The reason for that was the necessity of rebuilding the heating system in the lower part of the combustion chamber. The new localisation of ceramic 
elements and insulation mats has changed heat transfer process between the wall of combustion chamber and it's vicinity. The effects caused by the $\mathrm{O}_{2}$ concentration were isolated by keeping the thermal conditions similar to those in the tests and by maintaining the constant values of other factors.

\subsection{Pressure profiles}

Pressure measurements demonstrated that the strongest pressure fluctuations in the combustion chamber appear close to the grid in the dense phase $(\mathrm{P} 2: 0.01 \mathrm{~m})$ and weaken with the height of the combustion chamber. The biggest pressure fluctuation amplitude was measured in the lower part of the loop seal (P10: $0.55 \mathrm{~m})$. Pressure loop for the test rig was drawn based on received data, which confirmed a typical pressure distribution for CFB systems (Basu and Fraser, 1991). The total pressure drop inside the combustion chamber was kept at a level of ca. 2500 Pa for each test (Fig. 2b).

\subsection{Nitrogen conversion}

Conversion ratios of fuel- $\mathrm{N}$ to $\mathrm{NO}, \mathrm{NO}_{2}, \mathrm{~N}_{2} \mathrm{O}, \mathrm{NH}_{3}$ and $\mathrm{HCN}$ in $\mathrm{O}_{2} / \mathrm{CO}_{2}$ mixtures with different fraction of oxygen are shown in Figs. 3-4. A gradual rise of oxygen concentration in the secondary gas resulted in a significant drop in $\mathrm{N}_{2} \mathrm{O}$ formation (in tests 1-4 the value of $C R_{N \rightarrow N 2 O}$ factor calculated at the top of combustion chamber dropped by half). The effect of this reaction can be observed in the higher amount of $\mathrm{NO}$ being formed at that time, which suggests that $\mathrm{N}_{2} \mathrm{O}$ oxidises in a higher $\mathrm{O}_{2}$ concentration environment. A gradual rise of oxygen concentration in the secondary gas causes $\mathrm{N}_{2} \mathrm{O}$ concentration to drop. Along a decreasing $\mathrm{N}_{2} \mathrm{O}$ concentration, the increase of $\mathrm{NO}$ formation can be observed, which proves the $\mathrm{N}_{2} \mathrm{O}$ tendency to oxidise in high $\mathrm{O}_{2}$ environment. Furthermore, it is worth noticing that at a higher inlet- $\mathrm{O}_{2}$ concentration, $\mathrm{N}_{2} \mathrm{O}$ formation takes place in the lower part of the combustion chamber.
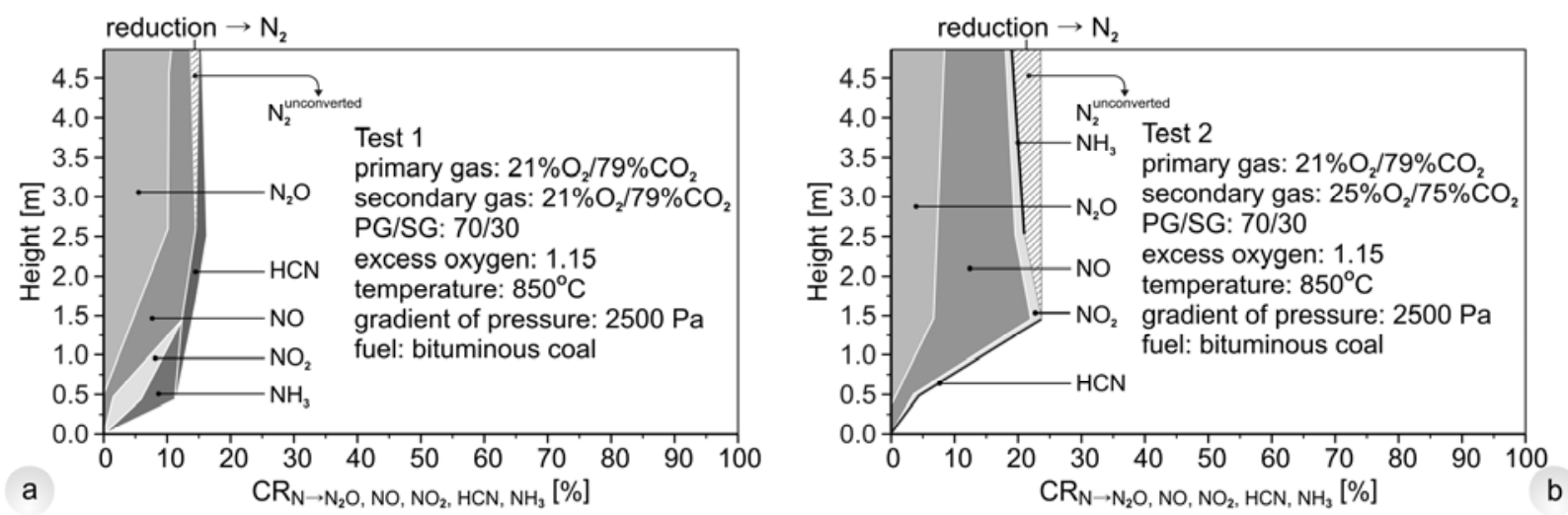

Fig. 3. Conversion ratio of fuel-N along the height of combustion chamber $-21 \% \mathrm{O}_{2}$ (a) and $25 \% \mathrm{O}_{2}$ (b)

The strongest influence of a higher $\mathrm{O}_{2}$ concentration can be observed in NO behaviour with the most significant differences near the secondary gas inlet $(0.55 \mathrm{~m})$. The reaction observed at FG1 level $(0.43 \mathrm{~m})$ seems to be connected with the injection of $\mathrm{O}_{2}$ present in the secondary gas to the combustion chamber. High turbulence and mixing is believed to force oxygen to be transported down towards the grid, thus creating an environment promoting NO formation.

Final emission of NO is defined by reduction processes (represented in Figs. 3-4 - hatched area) as described by reactions 1-4 that take place in the upper part of the combustion chamber and seems to be intensified with a higher oxygen concentration in the secondary gas (Tomeczek and Gil, 2001; Vix-Guterl et al., 1997; Miller and Bowman, 1989). 


$$
\begin{gathered}
\mathrm{NO}+\mathrm{C} \rightarrow 0.5 \mathrm{~N}_{2}+\mathrm{CO} \\
\mathrm{NO}+\mathrm{CO} \rightarrow 0.5 \mathrm{~N}_{2}+\mathrm{CO}_{2} \\
2 \mathrm{NO}+\mathrm{CO} \rightarrow \mathrm{N}_{2} \mathrm{O}+\mathrm{CO}_{2} \\
\mathrm{NO}+\mathrm{CxHy} \rightarrow \mathrm{HCN}+\ldots
\end{gathered}
$$

In comparison to $\mathrm{N}_{2} \mathrm{O}$ and $\mathrm{NO}$, the conversion ratio of $\mathrm{N}$ to $\mathrm{NO}_{2}$ can be considered as insignificant. Moreover, $\mathrm{NO}_{2}$ appears only in the lower part of the combustion chamber and does not seem to have any influence on the final $\mathrm{NO}_{\mathrm{X}}$ emission.
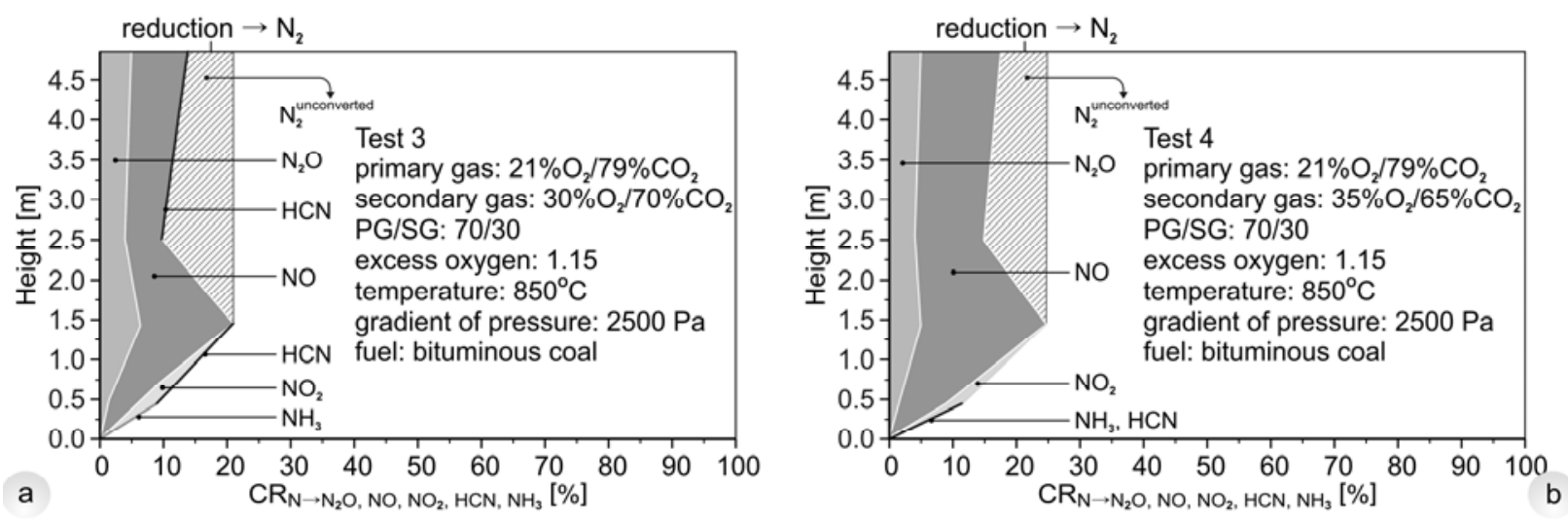

Fig. 4. Conversion ratio of fuel-N along the height of combustion chamber $-30 \% \mathrm{O}_{2}$ (a) and $35 \% \mathrm{O}_{2}$ (b)

The analysis of anaerobic forms of nitrogen showed, that ammonia exists mainly in the lower part of the combustion chamber. The conversion index of nitrogen to ammonia $\left(C R_{\mathrm{N} \rightarrow \mathrm{NH} 3}\right)$ decreased simultaneously with increasing oxygen content in the secondary gas. It is believed to have been caused by the process of oxygen transportation to the lower part of the combustion chamber as described in the case of NO. Furthermore, hydrogen cyanide appeared locally and the index value of $C R_{\mathrm{N} \rightarrow \mathrm{HCN}}$ was higher than $1 \%$ only during the second test, in which oxygen concentrations were the same in both primary and secondary gases.

\section{CONCLUSIONS}

Data presented in the article demonstrate that oxygen concentration in higher parts of the combustion chamber has a strong influence on the behaviour of nitrogen compounds nitrogen compounds behavior. An increasing $\mathrm{O}_{2}$ concentration in the secondary gas results in a significant reduction of $\mathrm{N}_{2} \mathrm{O}$ concentration in the flue gas. Simultaneously, the amount of formed NO raised significantly, which shows $\mathrm{N}_{2} \mathrm{O}$ susceptibility to pass to higher oxidation state in oxygen enriched gas atmosphere. In comparison to $\mathrm{N}_{2} \mathrm{O}$ and $\mathrm{NO}$, the conversion rate of fuel nitrogen to $\mathrm{NO}_{2}$ can be considered as insignificant. Furthermore, $\mathrm{NO}_{\mathrm{X}}$ reduction process was observed and was increasing with higher oxygen concentrations in the secondary gas.

Research and Development Strategic Program "Advanced Technologies for Energy Generation" project no.2 "Oxy-combustion technology for PC and FBC boilers with $\mathrm{CO}_{2}$ capture", supported by the National Centre for Research and Development, agreement no. SP/E/2/66420/10. 


\section{SYMBOLS}

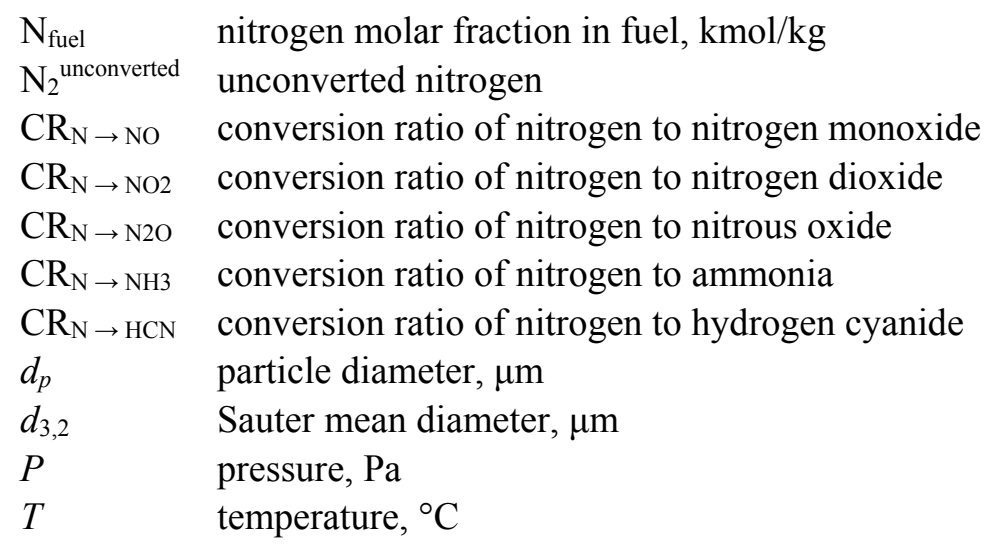

\section{REFERENCES}

Antoniades C., Christofides P.D., 2001. Studies on nonlinear dynamics and control of a tubular reactor with recycle. Nonlinear Anal. Theory Methods Appl., 47, 5933-5944. DOI: 10.1016/S0362-546X(01)00699-X.

Basu P., Fraser S.A., 1991. Circulating fluidized bed boilers - Design and operations. Butterworth-Heinemann, Stoneham, USA, 41.

Czakiert T., Nowak W., Muskała W., 2004. CFB oxy-combustion. Fluidization XI: Present and Future for Fluidization Engineering, Ichida, Italy, 9-14 May 2004.

Czakiert T., Muskala W., Jankowska S., Krawczyk G., Borecki P., Jesionowski Ł., Nowak W., 2012. Combustible matter conversion in an oxy-fuel circulating fluidized-bed (CFB) environment. Energy Fuels, 26, 5437-5445. DOI: 10.1021/ef3011838.

Eriksson T., Nuortimo K., Hotta A., Myohanen K., Hyppanen T., Pikkarainen T., 2008. Near zero $\mathrm{CO}_{2}$ emissions in coal firing with oxy-fuel CFB boiler. Proc. of the $9^{\text {th }}$ International Conference on Circulating Fluidized Beds, Hamburg, Germany, May 13-16, 819-824.

Glarborg P., Jensen A.D., Johnsson J.E. 2003. Fuel nitrogen conversion in solid fuel fired systems. Prog. Energy Combust. Sci., 29, 89-113. DOI: 10.1016/S0360-1285(02)00031-X.

Hirma T., Hosoda A., Azuma N., 1998. Drastic reduction of $\mathrm{NO}_{\mathrm{X}}$ and $\mathrm{N}_{2} \mathrm{O}$ emission from BFBC of coal by means of $\mathrm{CO}_{2} / \mathrm{O}_{2}$ combustion: Effects of fuel gas recycle and coal type (C). Int. Symp. of Engineering Foundation Fluidization IX, USA.

Lasek J.A., Janusz M., Zuwała J., Głód K., Iluk A., 2013. Oxy-fuel combustion of selected solid fuels under atmospheric and elevated pressures. Energy, 62, 105-12. DOI: 10.1016/j.energy.2013.04.079.

Liljedahl G.N., Turek D.G., Nsakala N.Y., Monh N.C., Fout T.E., 2006. Alstom's oxygen-fired CFB technology development status for $\mathrm{CO}_{2}$ mitigation. $31^{\text {st }}$ Int. Techn. Conf. on Coal Utilization and Fuel System, Clearwater, USA.

Miller J.A., Bowman C.T., 1989. Mechanism and modeling of nitrogen chemistry in combustion. Prog. Ener. Comb. Sci., 15, 287-38. DOI: 10.1016/0360-1285(89)90017-8.

Normann F., Andersson K., Leckner B., Johnsson F., 2009. Emission control of nitrogen oxides in the oxy-fuel process. Prog. Energy Combust. Sci., 35, 385-97. DOI: 10.1016/j.pecs.2009.04.002.

Pawlak-Kruczek H., Ostrycharczyk M., Baranowski M., Czerep M., Zgóra J., 2013. Co-firing of biomass with pulverised coal in oxygen enriched atmosphere. Chem. Process Eng., 34, 215-26. DOI: 10.2478/cpe-2013-0018.

Toftegaard M.B., Brix J., Jensen P.A., Glarborg P., Jensen A.D., 2010. Oxy-fuel combustion of solid fuels. Prog. Energy Combust. Sci., 36, 581-625. DOI: 10.1016/j.pecs.2010.02.001.

Tomeczek J., Gil S., 2001. Influence of pressure on the rate of nitric oxide reduction by char. Comb. Flame, 126, 1602-06. DOI: 10.1016/S0010-2180(01)00260-7.

Vix-Guterl C., Lahaye J., Ehrburger P., 1997. The catalytic reduction of nitric oxide by carbon monoxide over silica. Fuel, 76, 517-520. DOI: 10.1016/S0016-2361(96)00196-2.

Williams A., Jones J.M., Ma L., Pourkashanian M., 2012. Pollutants from the combustion of solid biomass fuels. Prog. Energy Combust. Sci., 38, 113-37. DOI: 10.1016/j.pecs.2011.10.001. 
S. Jankowska et al., Chem. Process Eng., 2014, 35 (4), 489-496

Received 04 April 2014

Received in revised form 04 October 2014 Accepted 08 October 2014 